\title{
Developing sustainable and liveable neighbourhoods: the role of public open spaces
}

\author{
A. I. Emenike \\ Faculty of Environmental Science, \\ Enugu State University of Science and Technology, Nigeria
}

\begin{abstract}
Neighbourhoods are designed to be liveable and, most times, sustainable. In doing this, neighbourhoods are designed for single density, mixed use or compact where the various land uses are to complement one another. Public open space is an essential land use of a neighbourhood. The study aims at highlighting the role that public open space plays in making neighbourhoods sustainable and liveable. The study employed a descriptive research method whereby some layouts were visited, their public open spaces and effects noted and literature on sustainability, public open spaces and liveable neighbourhoods were appraised. The study showed that public open spaces have a very significant role in making these layouts liveable and sustainable such as calming effects on pollution, lowering of urban heat island and could also be used for green infrastructure.
\end{abstract}

Keywords: develop, liveable, neighbourhood, public open spaces, role, sustainable.

\section{Introduction}

Urban centres are divided into neighbourhoods for easy planning and management of the different land uses and facilities. Land use planning is a way of putting compatible land uses together and using some land use to shield others from harm that is shielding incompatible ones. Such is the cases of public open spaces as a land use. That is, it is used to shield, to cut off land uses from each other or connect others and so provide protection to the environment and inhabitants. Public open space as a land use is seen as land built upon, used in interconnectivity of other land uses. Open spaces comprise such things as gardens, playground, parks, trails, 
streets, roads, pedestrian walkways, setbacks within individual plots, etc. (Emenike [1]).

The study hopes to stress the importance and role of public open spaces especially within the neighbourhoods. This can be done by showing the number of public open spaces in a planned neighbourhood, and their uses and effects on the neighbourhood generally.

With the downturn in the economy where most landowners want to make the most of their landed resources coupled with the recent planning trend in this part of Nigeria, whereby layouts are made by communities and private individuals. The outcome is the plot sizes are smaller with very little provision of service plots (waste disposal, transformer station, etc), narrow roads, no pedestrian walkways, no parks, no playground, etc. in fact most of these public uses plots even when available on paper are not implemented. Some very new layouts are not opened up (no roads constructed, no amenities put in place) before new developments (houses/buildings) spring up. The absence of public open spaces or very little provision means there will be a lot working against the liveability of the neighbourhoods created. With the scenario as shown there is a strong need to set a standard especially as regards public open spaces which must be enforced. This forms a discussion for another study.

\section{Conceptual framework}

The conceptual framework of this study is based on the basic principle and concept of sustainable development whereby the role of public open spaces forms the nucleus for a sustainable urban environment. This will help in making neighbourhoods liveable, also be able to regenerate themselves and still remain useful for the future.

\subsection{Public open space}

Open spaces are defined as an area of land or water that either remains in its natural state or is used for agriculture, preserved from intensive development for residential, commercial, industrial or institutional use (DEC [2]). It could be taken as all of open spaces of public value, including not just land but also areas of water such as rivers, canals, lakes and reservoirs. It is also defined as all of landscape, hardscape (roads, sidewalks, road median, pedestrian walkways), parks, recreational spaces, squares, urban greenways, trails, rail or utility corridors (Daniels and Daniels [3]). Open spaces help in defining the form of the city which expresses ideas about the cultural value system and also enhance the urban environmental aesthetics making the city pleasing and agreeable (Emenike [4]). Public open space is of various types and so has different uses ranging from public parks used for recreation and relaxation, set-backs used to let in air and light into the various living quarters, roads and footpaths used for circulation and connecting all the other land uses, vacant spaces that could be used in channelling flood water and so on. 


\subsection{Sustainability}

Sustainability is the capacity to endure that is potential for long-term maintenance of well-being (Emenike [5]). It is the capacity for continuance into the future and recognises that life is a complex bundle of values, objectives and activities with ethical, environmental, economical and social dimension. Sustainability means replenishing renewable resources and conserving non renewable ones by recycling, reuse, etc. It also means not to overburden the regenerative capacity of natural systems. Sustainability is a social challenge that requires international laws, a change in local and individual life styles and ethical consumerism, sustainability generally requires control to achieve the following environmental efficiency, conservation of natural resources, maintenance of health and enhancement of social equality. This study is more on environmental efficiency whereby all public open spaces will aid the liveability of neighbourhoods.

\subsection{Neighbourhood}

Neighbourhood unit is described as a populated area that would require and support an elementary school as stated by Clarence Perry (Gallion and Eisner [6]).

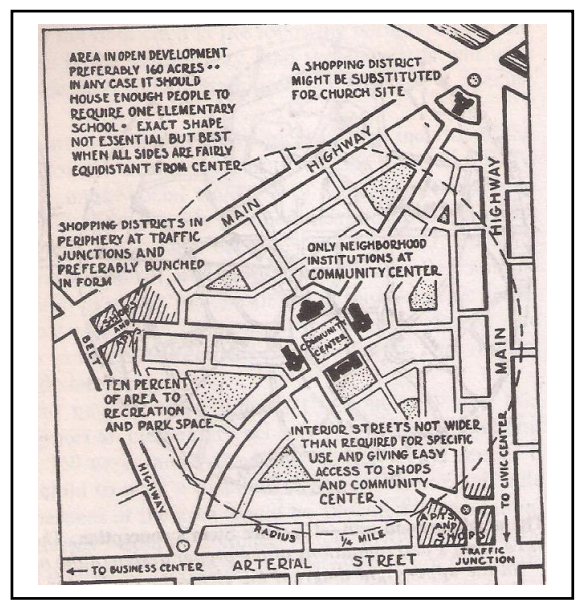

Figure 1: Neighbourhood unit by Clarence Perry (source: Gallion and Eisner [6]).

It is surrounded by through traffic and internal roads being only services routes. This has characterised neighbourhood planning to date and neighbourhood is seen as the basic urban unit. Neighbourhood planning is based on the belief that modern city is an organism comprised of individual cells (neighbourhood), an ideal unit in which to concentrate planning programmes (Catanese and Snyder [7]). In neighbourhood planning the size $(2,000-10,000)$ of neighbourhood determines the facilities and series to be provide. The land uses are most often missed through residential (housing) gets the largest land allocation (Obateru [8]), see table 1 below. 
Table 1: Land use allocation in a neighbourhood (source: Obateru [8]).

\begin{tabular}{|l|l|l|}
\hline s/no & Land use & Percentage \\
\hline 1 & Residential (housing) plot & $50-60$ \\
\hline 2 & Roads/streets & $12-25$ \\
\hline 3 & Commercial & $3-5$ \\
\hline 4 & Recreation & $6-8$ \\
\hline 5 & Utilities, facilities and services & $10-15$ \\
\hline Total & \multicolumn{2}{|l|}{100} \\
\hline
\end{tabular}

Neighbourhoods once created undergo changes in quality due majorly to the interest of the inhabitants (Knox and McCarthy [9]). These changes manifest in investments/disinvestment within the neighbourhood, physical deterioration and obsolescence especially in the housing stock and infrastructural amenities, household mobility and social/demographic change, etc to maintain neighbourhood at the quality it was designed it becomes pertinent to introduce things that will enhance the liveability of the unit such as public open spaces.

\section{Effects of public open space on neighbourhoods}

Public open spaces in neighbourhoods could be portions of land of scenic value, historic importance, area subject to flooding; areas too steep to be built on, etc and so are set apart. These public open spaces are for interconnectivity (roads, paths, drains, etc), recreation (parks, playgrounds, play lots, etc.) and green reserve (buffer, greens, trails, green infrastructure). These public open spaces are designed to humanize the urban environment, serving human as well as birds (Chukwumereije [10]). To bring nature into synthetic concrete environment, making cities more liveable. Public open spaces influence our general life; health, wellbeing, physical development, etc.

\subsection{Road network}

The urban structure must be designed and redesigned as a series of physically functioning neighbourhoods with defined circulation system. Road network is the system of interconnected roads designed to accommodate wheeled road vehicles and pedestrian traffic which forms the most basic level of transportation infrastructure within urban areas (Securipedia [11]). The major highways define the boundaries of the neighbourhood, while the internal streets comprise service/access roads and pedestrian pathways. A good coordination ensures better pedestrian safety through better street design, use of traffic lights, the slowing of traffic where pedestrian movement is greatest.

Road network affect everyday life through; social (facilitates movement of people for social interaction), economic (facilitates movement of people, goods and services), mobility (facilitating movement from one area to another), safety (prevention of accidents through speed controls, etc), security issues (influences mobility of public and also criminals) and so on. 
Roads within the neighbourhoods are primarily of three types; distributor (collector), service access (street) and cul-de-sac (dead end street).

\subsection{Parks}

Neighbourhood parks are small areas of open spaces reserved for formal and informal sports and recreation. They vary in size, form and function providing generally recreation for children play, adult relaxation and playing fields for organised sports [12]. Neighbourhood recreation should be accessible to inhabitants at walk able distant with security guaranteed.

\subsection{Green infrastructure}

Green infrastructure is a network providing the ingredients for solving urban and climatic challenges by building with nature (Wikipedia [13]). It also serves to provide ecological framework for social, economic and environmental health of the surroundings. These green reserves in the neighbourhood give form to urban community, preserve freshness of air, lowers urban heat island (UHI), provides home for biodiversity, provides for urban agriculture and generally separates urban development from rural area. It is all about natural environment in urban areas commonly used for storm water management, climate adaption and multifunctional green space (integration and interaction of different functions and activities on the same piece of land).

\section{The study}

The study is on existing neighbourhoods, evaluating how liveable and sustainable they are and ways of improving their present standards. The chosen layouts will be visited and their physical conditions noted.

\subsection{Study area}

The study is on Enugu metropolis in south eastern Nigeria. Enugu is the capital of Enugu State. It lies in the south-eastern foot of Udi hills, about $93 \mathrm{~km}$ (58 miles) north east of Onitsha. It is on latitude $7^{\circ} 29^{\mathrm{I}}$ north of the equator and $6^{\circ} 27^{\mathrm{I}}$ east of the Greenwich. The present city was founded in 1909 after coal deposits were discovered at the nearby village of Enugwu Ngwo by a team of British geologists and acquired township status in 1917 as a second class town (Emenike [14]).

\subsection{Research methodology}

The study will employ survey research method which is descriptive in nature using some descriptive and analytical tools. There will be three layouts chosen; Federal Housing Trans Ekulu is a low income layout, New Haven is a medium income layout and Independence Layout is a high income layout. The types of data to be collected fall into primary and secondary. The primary data comes from the fieldwork while secondary data will come from documented reviews, maps, etc. 
Data collected will be presented in graphical form (tables, charts, graphs) for easy comprehension and analysis.

\subsection{Research question}

To view this study properly the following research questions were formulated;

- How many land uses were utilized in neighbourhoods in Enugu?

- How many densities can be accommodated in these neighbourhoods?

- What types of public open spaces are available within these neighbourhoods?

\section{Presentations of results: discussion of findings}

\subsection{Presentations of results}

In the course of this study, the search was tailored towards the research questions already posed and the following were the outcome.

- How many land uses were utilized in neighbourhoods in Enugu? It was found out that the major land uses considered in these neighbourhoods were mixed. The residential land use is the major determinant of the density type before other land uses like commercial, light industrial and service plots are added. The residential plot size for low density is between $1200 \mathrm{~m}^{2}-2000 \mathrm{~m}^{2}$ while the size for medium density plot is between $800 \mathrm{~m}^{2}-1200 \mathrm{~m}^{2}$ and that of high density plot is between $450 \mathrm{~m}^{2}-600 \mathrm{~m}^{2}$. This is shown in table 2 overleaf;

- How many densities can be accommodated in these neighbourhoods? The results showed that each neighbourhood was designed for a particular density and implemented as such but as the day go by filtration and gentrification sets in, the neighbourhood gets mixed up. At times there is change in use taking place which changes a lot of the initial plans for the neighbourhood.

- What types of public open spaces are available within these neighbourhoods? The result showed that the public open spaces usually provided in a neighbourhood are a mixture of parks, playground, roads, drains, green reserve, etc.

\subsection{Discussion of findings}

The findings, as stated above, showed that the planning of Enugu metropolis as a city did not deviate from core planning principles very much. Going through table 2 above it could be seen that some land use types are under provided. Taking the third layout, Abakpa Nike for instance there is provision for 119 residential plots, only 1 public use plot, 3 open space plots, etc. Note that public use plots are for schools, churches, hospitals, police post, etc. Utility plots are for refuse dump, electricity transformer station, etc. Open space plots are for playground, recreation ground and so on. In the light of the above there is gross under provision of these land use types bearing in mind that this neighbourhood is a high density layout. 


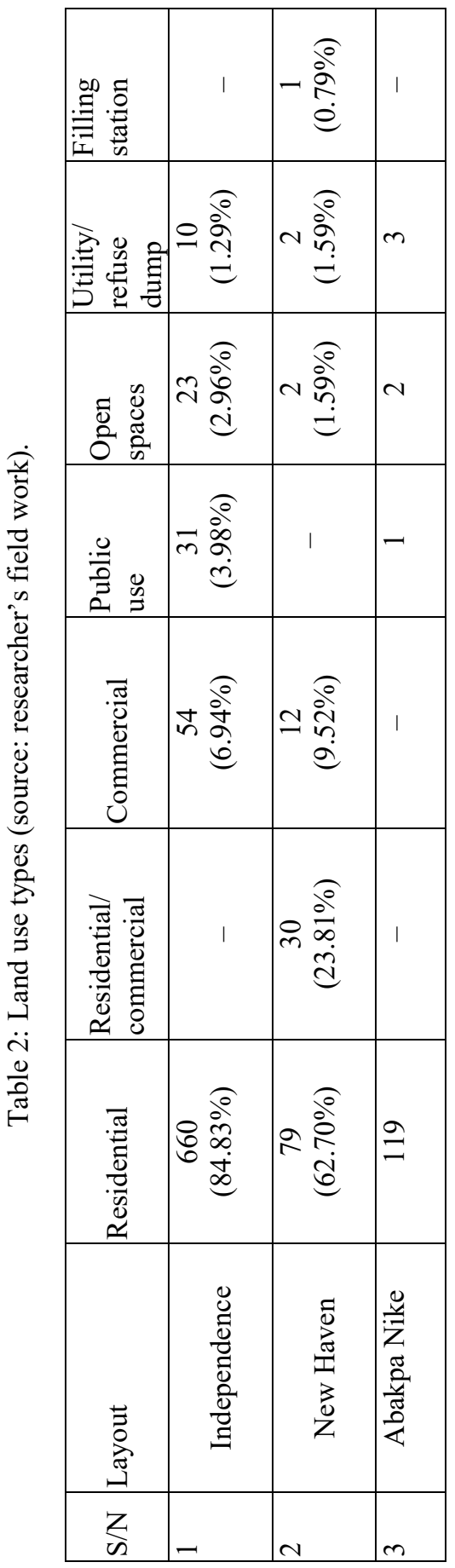




\section{Conclusion/recommendation}

In conclusion therefore, the researcher wishes to state that public open spaces are very necessary for human health, human development and ecological wellbeing. The relevance of public open spaces in our neighbourhood in particular and in the built environment generally can never be over-emphasized. Therefore, all those in authority, the decision makers, urban planners, architects, etc should help revive our city by opening up, creating more public open spaces, maintaining the public open spaces for a more sustainable neighbourhood for future generations.

\section{References}

[1] Emenike, A. I., Evaluation of Environmental and Landscape Qualities of Public Open Spaces in Enugu Metropolis. Unpublished doctoral thesis to Enugu State University of Science and Technology, Enugu, 2014.

[2] DEC, Open Space-New York State Department of Environmental Conservation, 2012.

[3] Daniels, T. and Daniels, K., The Environmental Planning Handbook for Sustainable Communities and Regions. Planners Press: Chicago.

[4] Emenike, A. I., Evaluation of Environmental and Landscape Qualities of Public Open Spaces in Enugu Metropolis. Unpublished doctoral thesis to Enugu State University of Science and Technology, Enugu, 2014.

[5] Emenike, A. I., The Use of Sustainable Architecture as an Environmental Management Strategy in Urban Cities in Nigeria. Journal of Civil Engineering and Architecture Research 3(2) pp. 1293-1298, 2016.

[6] Gallion, A. B. \& Eisner, S., The Urban Patterns City Planning and Design. CBS Publishers: New Delhi.

[7] Catanese, A. J. \& Snyder, J., Introduction to Urban Planning. McGraw-Hill Book Company: New York.

[8] Obateru, O., Land Subdivision Guide Evan Brothers (Nigeria Publishers) Ltd: Ibadan.

[9] Knox, P. L. \& McCarthy, L., Urbanization: An Introduction to Urban Geography. Pearson Prentice Hall: New Jersey.

[10] Chukwumereije, O. Parks and Urban Life. http://www.nigeriansin america.com/parks-and-urban-life

[11] Securipedia, Roads Network. Securipedia.eu/mediawiki.index.php/Roadnetwork (accessed on 28/04/16).

[12] Parks and Open Space. www.healthyplaces.org (accessed on 20/04/16).

[13] Wikipedia. Green Infrastructure. (accessed on 20/04/16).

[14] Emenike, A. I., Evaluation of Environmental and Landscape Qualities of Public Open Spaces in Enugu Metropolis. Unpublished doctoral thesis to Enugu State University of Science and Technology, Enugu. 2014. 